\title{
Costa Rican Theatre, Summer 2005
}

\section{Deb Cohen}

This past July in San José, I met with playwrights Jorge Arroyo, Claudia Barrionuevo, Leda Cavallini, Roxana Campos, Wálter Fernández, Ana Istarú, César Meléndez, Melvin Méndez and Miguel Rojas. From our informal discussions, I learned that the theatre is very much alive in San José, but not necessarily lucrative. Many dramatists write and/or act for television, or serve as directors in order to make ends meet. In general, these playwrights focus on one or two thematic areas. Leda Cavallini, Roxana Campos, Claudia Barrionuevo, Melvin Méndez and Ana Istarú mainly concern themselves with criticizing aspects of contemporary Costa Rican society (especially gender roles), while Miguel Rojas and Jorge Arroyo retain an interest in reconstructing the national past.

Claudia Barrionuevo's latest play, Mi mamá, ¿me ama?, was in its last weeks at the Laurence Olivier theatre (next to the Sala Garbo indie film house). This acclaimed piece (it won second place in the 2003 María Teresa León drama competition in Spain) breaks with the well-made play tradition, retracing one event in real time as it occurs in three different versions. Expertly acted by a cast including the playwright's mother (for whom the part was expressly written), Barrionuevo explores the relationship between the swinging free-thinking grandmother, Virginia, her uptight middle-aged daughter, Elena, and her feisty granddaughter, Fusa. All three acts begin at 5:30 pm on May 15 , Fusa's birthday. To set the "real time" in motion, in the first act, one actor places a battery in the clock; in following acts, as the actors "rewind" themselves and the props to their initial positions, someone also resets the clock. Also important in each act is the special necklace, or amulet, from the north of Argentina that Virginia brings Fusa for her birthday. She says its magical powers will grant Fusa three wishes. Consequently, Fusa's frustration from the events that have occurred in each of the three acts causes her to 
wish for something that changes the next act slightly. By the epilogue, which takes place previous to the other acts (at $4: 30 \mathrm{pm}$ the same day), Fusa's three wishes have resolved her problems, and Virginia has somehow lost the magic amulet in her travels from Argentina to San José.

Barrionuevo populated her earlier plays entirely with female characters. In a recent interview, she confessed that it was a challenge for her to write her first male character, whom she wanted to be sympathetic, yet realistic. She obviously succeeded, because Manuel, Fusa's lover, is sensitive, attentive, self-assured and also comically clumsy. Fusa, who has avoided serious relationships with Costa Rican men because of the philandering of the men in her family, feels safe with Manuel because he is Chilean. However, in the first act, Virginia reveals that he is the illegitimate son of her ex-husband (Fusa's grandfather), who once had a fling while visiting Chile. Thus, the taboo of incest suddenly creates a serious dilemma from which there seems to be no exit, until Fusa makes the first of her three wishes. In this way, Barrionuevo generates suspense, as the audience or reader waits to see how each act will change Fusa's and Manuel's fate. Although the play received a literary prize and good reviews, it suffered poor attendance due to its venue. The Teatro Laurence Olivier is located away from the center of San José, and parking in the otherwise residential area is hard to find.

The inauguration of the newly renovated Teatro Vargas Calvo, the small theatre located behind the Teatro Nacional and administered by its director, Samuel Rovinski, took place July 22. Rovinski chose to honor tico Miguel Rojas by producing El saxofón (formerly Madriguera de ilusiones). The original play, a dark piece about an avaricious money-lender, his drunk friend and their landlady, sets up power plays among the characters, as each vies to wrest Clavija's money from him. After her attempt to seduce Clavija fails, Azucena suffocates him with a pillow. In the second act, the tables are turned as Cancán murders Azucena the same way. In the brief epilogue, the characters make peace with each other and reach some kind of understanding as they wait in a sort of limbo to move on. Although Rojas initially took great pains to refrain from publicly judging the new production, as the evening wore on, he began to admit privately to some misgivings about its direction. The director, Mariano González, made drastic cuts to the second act. In addition, instead of Cancán suffocating Azucena, in this version Cancán stabs her with a knife. Andrés Sáenz, theatre critic for La Nación, voiced similar concerns in his review published July 25: 
El espectáculo dura alrededor de 65 minutos y durante 50 de ellos mantuvo mi interés gracias a las circunstancias enigmáticas de las situaciones; al juego semi-paródico de los actores; a la ambientación sugestivamente sórdida lograda por la escenografía de David Vargas; a la vestimenta estrafalaria diseñada por Rolando Trejos; a las sugerentes intervenciones musicales del Saxofón, interpretado por Lalo Rojas, hijo; a las réplicas ágiles y chistosas del diálogo y al ritmo movido de la escenificación de[1 director Mariano] González. Sin embargo, la obra se desplomó en los últimos 15 minutos por causa de un desenlace burdo y trillado que, pese al breve cambio de escena final, dejó la trama irresuelta e inconclusa.

Because of similar infelicitous directions (certainly not exclusively a Costa Rican phenomenon), some tico playwrights such as Claudia Barrionuevo and Melvin Méndez choose to produce and direct their own plays.

Another restaging took place a week earlier in the Teatro Lucho Barahona to celebrate the twentieth anniversary of the eponymous director's initial production of L'Anima sola de Chico Muñoz by Jorge Arroyo. Written when Arroyo was barely nineteen years old, the costumbrista piece celebrated more than 350 performances in its first run, and played to an almost full house the night I saw it. The play literally and figuratively centers on the recently deceased Chico Muñoz, onstage in an ever-present coffin. His family and friends await the arrival of a mysterious stranger, without whose presence they cannot fulfill Chico's dying wish, thus delaying his burial. Meanwhile, family and friends gather for the free food and drink that the velorio offers. Calling this piece a "clásico del teatro costarricense," Barahona suggests that it is successful because "pinta la hipocresía y la doble moral de los ticos, la permanente manipulación religiosa en que vivimos, el arribismo, las componendas politiqueras y las matráfulas que produce nuestra mentalidad de pueblón" (playbill). The scenography was a basic and low-budget sala, and the eccentric characters were brought to life through creative costumes and makeup. Furthermore, the lively dialogue and the excellent acting barely left the audience time to catch its breath between guffaws. Some of the bit players' stage business generated waves of laughter from the audience even when they were not speaking. The audience included many families, and most of the play's suggestive remarks were couched in seemingly-innocent language that children could take at face value, while the adults enjoyed the double-entendre. To keep the costumbrista element alive, Barahona played Costa Rican popular music as the audience entered, during the intermission, 
and at the end of the play. Most of Arroyo's earlier works are also costumbrista pieces (Con la honra en el alambre, 1987; El surco entre el flor y el labio, 1997; La tertulia de los espantos, 1997). Like Miguel Rojas, he has lately turned to writing historical theatre based on national heroes such as the founding fathers (La patria primera: hombres de fecunda labor , 2004) and martyr to independence Juan Santamaría (La tea fulgurante 2004).

César Meléndez continues to provoke audiences at home and abroad with his one-man show, El Nica, which deals with Nicaraguan migration to Costa Rica. He and his wife, Cristina Bruno also have a regular gig on Wednesdays at the Café Tokú in the suburb of Escazú with their play $L a$ telenovela Flora. This piece started out as a tool for sensitivity training in San José industrial settings. In it, Meléndez plays a typical tico macho, and Bruno plays his submissive wife. Eventually, the audience is asked to give the characters advice on how to improve their behavior and overcome stereotypical gender roles. The evening I saw the show, at least half the audience worked for TACA (one of the Meléndez's corporate sponsors), and had complimentary tickets. Furthermore, they received preferential seating near the stage, and were the ones chosen to participate in the show. There is no denying that Meléndez is a talented actor, but his relentless self-promotion ("Come back and see el Nica on Sunday") and corporate backing (Café Britt, as well as TACA) puts his theatre in a different category than the playwrights mentioned above. His present success may also be hindering his development as an artist - he has not written or performed in anything new in several years.

There is now a younger group beginning to write and produce plays, both in San José and in the provinces. Miguel Rojas mentioned Luis Greivin Valverde Soto as someone to watch. With Rojas and Cavallini training the next generation in the Escuela de Artes Dramáticas at the Universidad de Costa Rica, the country's theatre seems to be entering a period of maturation and plenitude, in spite of ever-worsening economic conditions. 